University of Nebraska - Lincoln

DigitalCommons@University of Nebraska - Lincoln

Faculty Publications from the Harold W. Manter Laboratory of Parasitology

2012

\title{
Zoonotic and Human Parasites of Inhabitants of Cueva de los Muertos Chiquitos, Rio Zape Valley, Durango, Mexico
}

\author{
F. Agustín Jiménez-Ruiz \\ Southern Illinois University Carbondale, agustinjz@zoology.siu.edu \\ Scott Lyell Gardner \\ University of Nebraska - Lincoln, slg@unl.edu \\ Adauto Araújo \\ Fundação Oswaldo Cruz, adauto@ensp.fiocruz.br \\ Martín Horacio Fugassa \\ Consejo Nacional de Investigaciones Científicas y Técnicas \\ Richard H. Brooks \\ University of Nevada, Las Vegas \\ See next page for additional authors \\ Follow this and additional works at: https://digitalcommons.unl.edu/parasitologyfacpubs \\ Part of the Archaeological Anthropology Commons, Biodiversity Commons, Parasitic Diseases \\ Commons, and the Parasitology Commons
}

Jiménez-Ruiz, F. Agustín; Gardner, Scott Lyell; Araújo, Adauto; Fugassa, Martín Horacio; Brooks, Richard H.; Racz, Elizabeth; and Reinhard, Karl J., "Zoonotic and Human Parasites of Inhabitants of Cueva de los Muertos Chiquitos, Rio Zape Valley, Durango, Mexico" (2012). Faculty Publications from the Harold W. Manter Laboratory of Parasitology. 765.

https://digitalcommons.unl.edu/parasitologyfacpubs/765

This Article is brought to you for free and open access by the Parasitology, Harold W. Manter Laboratory of at DigitalCommons@University of Nebraska - Lincoln. It has been accepted for inclusion in Faculty Publications from the Harold W. Manter Laboratory of Parasitology by an authorized administrator of DigitalCommons@University of Nebraska - Lincoln. 


\section{Authors}

F. Agustín Jiménez-Ruiz, Scott Lyell Gardner, Adauto Araújo, Martín Horacio Fugassa, Richard H. Brooks, Elizabeth Racz, and Karl J. Reinhard 


\title{
ZOONOTIC AND HUMAN PARASITES OF INHABITANTS OF CUEVA DE LOS MUERTOS CHIQUITOS, RIO ZAPE VALLEY, DURANGO, MEXICO
}

\author{
F. Agustín Jiménez, Scott L. Gardner*, Adauto Araújo†, Martín Fugassał, Richard H. Brooks§, Elizabeth Racz*, and \\ Karl J. Reinhard $\| \#$ \\ Department of Zoology, Southern Illinois University, Carbondale, Illinois 62901-6501. e-mail: kreinhard1@mac.com
}

\begin{abstract}
We present the first reconstruction of the parasitoses among the people of the Loma San Gabriel culture, as represented by 36 coprolites excavated from the Cueva de los Muertos Chiquitos in Durango, Mexico. The coprolites date to approximately 1,400-yrago. Species identified based on eggs recovered include the trematode Echinostoma sp., the tapeworms Hymenolepis sp. and Dipylidium caninum, and the nematodes Ancylostoma duodenale, Enterobius vermicularis, and Trichuris trichiura. After rehydration and screening, 2 methods were used to recover eggs from these samples including spontaneous sedimentation and flotation. Samples were analyzed by 3 different laboratories for independent verification and comparison of methods. Spontaneous sedimentation resulted in the discovery of hymenolepidid eggs that were not found with flotation. Sedimentation was a more-sensitive indicator of prevalence as well. The modified method of flotation permitted estimation of egg concentration and resulted in the detection of a few specimens not found by sedimentation. The results of both methods showed that 19 (of 36) coprolites contained helminth eggs. Our results detected the presence of pathogenic helminths including hookworms and whipworms. The cestodes found do not cause severe pathology in humans. The early dates of hookworm and whipworm, relative to other findings in the southwest United States, indicate that these parasites arrived relatively late in prehistory in Arizona and New Mexico, probably moving into the area with travelers from Mesoamerica.
\end{abstract}

The first dietary reconstruction of Mesoamerican societies was based on the analysis of coprolites from the valley of Tehuacán (Callen, 1965, 1967; McNeish, 1967). This reconstruction addressed over 8,000 yr of Mexican indigenous cultural development, from egalitarian hunter-gatherers to complex civilizations. However, the study of parasites was not included in that research. After Callen's death, the Tehuacán collection was moved to the Department of Anthropology at Texas A\&M (Bryant, 1974, 1975). One of us (K. J. Reinhard, pers. obs.) examined the collection, but no unprocessed coprolites were preserved by Callen to be tested for parasites. Therefore, an opportunity to examine the effect of the rise of civilization on parasitism was lost. Such a study was completed on the Colorado Plateau on the margins of ancient Mesoamerican civilization (Reinhard, 1987). However, the geographic connection of parasitism on the Colorado Plateau with Mesoamerica could not be evaluated because coprolites were not studied from Mexico. The analysis of coprolites from the site of Cueva de los Muertos Chiquitos in central Durango, Mexico provided us with the first glimpse into the parasitological state of Mesoamerica. The site is also important because it is on the frontier of the American Southwest and Mesoamerica. Therefore, we can gain insight into the transfer of parasites between Mesoamerica and the Southwest in ancient times. The present study thus helps to fill the gap in our knowledge of Mesoamerican parasitology and parasite biogeography.

The archeological site of Cueva de los Muertos Chiquitos is located in the northern Durango region of el Zape in the

Received 13 July 2011; revised 7 October 2011; accepted 20 October 2011.

* The Harold W. Manter Laboratory of Parasitology, University of Nebraska State Museum, University of Nebraska, Lincoln, Nebraska 68588-0514.

†Escola Nacional de Saúde Pública, Fundação Oswaldo Cruz, Rua Leopolda Bulhões 1480, 21041-210 Rio de Janeiro, RJ, Brazil.

†Consejo Nacional de Investigaciones Científicas y Técnicas, Departamento de Biología, Facultad de Ciencias Exactas y Naturales, Funes 3250, 7600 Mar del Plata, Argentina.

$\S$ Department of Anthropology, University of Nevada, Las Vegas, $4505 \mathrm{~S}$. Maryland Pkwy Mailstop 455003, Las Vegas, Nevada, 89154-5003.

" School of Natural Resources, University of Nebraska, Lincoln, Nebraska 68583-0987.

\# To whom correspondence should be addressed.

DOI: 10.1645/GE-2915.1 transition zone between the greater Southwest and the northernmost edge of Mesoamerica (Kelley, 1956, 1971; Brooks and Brooks, 1980). Located about $18 \mathrm{~km}$ SE of Guanaceví, Durango, with a sub-humid climate, this rocky valley has a series of caves that have been shown to provide excellent preservation of coprolites. Aboriginal inhabitants of the region belonged to the Mesoamerican culture known as Loma San Gabriel and occupied the region of southern Chihuahua and northern Durango 1,200to 1,400-yr-ago (Brooks et al., 1962; Foster, 1986). They have been characterized as sedentary villagers with the ability and knowledge to practice agriculture and also to pursue hunting and gathering (Kelley, 1956, 1971; Brooks et al., 1962; Foster, 1985).

Previous research has shown that, once human remains were deposited in the site, burials and middens were sealed with an adobe layer that prevented disturbance (Brooks et. al., 1962; Brooks and Brooks, 1980). Skeletons discovered in this area include 7 children ranging in age from a few months to 5-yr-old. The burials included food offerings consisting of corn, beans, agave, piñón, and cucurbits as well as necklaces of marine shells, belts, and wooden plaques with turquoise inlays (Brooks et al., 1962). The objects from this part of the cave were dated to about 600 A.D. Additional burials of an adult and 1 infant were placed over the older tomb at some later date (Brooks et al., 1962; Brooks and Brooks, 1978, 1980). Evidence of skeletal lesions in the human remains is apparent (D. Martin, pers. comm.).

Several techniques were employed to recover the remains of parasites from a variety of archaeological materials, including mummy tissues (Allison et al., 1974; Guhl et al., 1997), latrine sediments (Warnock and Reinhard, 1992; Bouchet et al., 2003), and coprolites (Szidat, 1944; Pizzi and Schenone, 1954; Taylor, 1955; Samuels, 1965; Reinhard et al., 1988; Ferreira et al., 2000). The trisodium-phosphate rehydration technique has become the most widely applied method for the study of coprolites and mummy intestinal contents (Reinhard, 1992; Reinhard and Bryant, 1992, 2008). This method results in the recovery of dietary and parasitological material (Callen and Cameron, 1960) and has been widely applied in North America (Samuels, 1965; Reinhard et al., 1988; Reinhard, 1992; Ferreira et al., 2000; Reinhard and Bryant, 2008). Thus, there is a body of data for desert regions that allows for comparison of prehistoric infection across time, cultural adaption, and geography for the desert west 
of North America (Reinhard 1992; Reinhard and Bryant, 2008). The analysis of the external appearance of stools also offers the testimony of some symptoms suffered by individuals under study, i.e., diarrhea. The analysis of their contents provides direct evidence of both feeding habits and parasitoses (Reinhard, 1992; Araújo and Ferreira, 2000; Araújo et al., 2003). Used in combination, the results of dietary and parasitological examinations may assist in the reconstruction of the interactions of ancient humans with their environment, settlement conditions, diet, hygiene, health (Araújo et al., 2003; Sianto et al., 2005), and trade routes (Ferreira et al., 1979, Araújo et al., 2003, Costa et al., 2009).

The present study offers insights on the parasites infecting people in El Zape valley in a site that predates other examined cultures in the Greater Southwest. Our analysis of coprolites followed 2 methods in 3 different laboratories. Therefore, our goals include (1) documenting the parasites present at the Cueva de los Muertos Chiquitos, and (2) providing definitive data on the relative efficacy of different methods of analysis of coprolites.

\section{MATERIALS AND METHODS}

Coprolites from different proveniences were collected in Cueva de los Muertos Chiquitos and placed into individual plastic and paper bags in the field by Sheilagh and Richard Brooks. The samples were stored in stable dry and temperate conditions; these were labeled by grid square and stratigraphic level of the excavation unit. We sampled one coprolite from each grid and excavation unit in order to maximize the chances of sampling a variety of the cave's prehistoric inhabitants. In a positivepressure, filtered-air laboratory (University of Nebraska, Lincoln, Nebraska), samples of 36 coprolites were placed in new plastic bags by gloved laboratory workers. We believe, based on diversification of samples, that we sampled 36 individuals. Each coprolite was described, photographed, and weighed. From each sample, 2 fragments of $2 \mathrm{~cm}^{3}$ each were removed with the aid of a clean spatula. One set of samples was processed at the University of Nebraska for parasite remains. A second set was submitted to the Molecular Anthropology Laboratories at the University of Oklahoma (Norman, Oklahoma) for DNA analysis (Tito et al., 2008). Molecular analysis of parasite DNA is on-going.

The samples were weighed and rehydrated in $0.5 \%$ trisodium phosphate for $48 \mathrm{hr}$. A tablet of Lycopodium (batch 212761, each containing 12,500 \pm 400 Lycopodium spores, University of Lund, Sweden) was added to the rehydrating coprolites. This was done to aid in the quantification of parasite eggs from the coprolites (Warnock and Reinhard, 1992; Sianto et al., 2005). The rehydrated coprolites were then screened through a $250-\mu \mathrm{m}$ mesh with distilled water. The water and microscopic residues that passed through the screen were collected in a beaker and concentrated by centrifugation. The concentrated sediments were divided into 3 subsamples to be analyzed at 3 separate laboratories, i.e., the archaeoparasitology lab in the School of Natural Resources at the University of Nebraska-Lincoln, the Laboratório de Paleoparasitología, Departamento de Biología, Universidad Nacional de Mar del Plata (Mar del Plata, Argentina), and the Laboratório de Paleoparasitología da Escola Nacional de Saúde Pública (Rio de Janeiro, Brazil).

At the University of Nebraska, the sediments were centrifuged and the pellet (usually $1 \mathrm{ml}$ ) was resuspended in Sheather's solution in 15-ml glass centrifuge tubes. The solution was added until it filled the tube. A coverslip was placed over each tube in direct contact with the solution. The tubes were spun at 1,000 $\mathrm{g}$ (Pritchard and Kruse, 1982; Gardner and Duszynski, 1990). The resulting coverslip was mounted on a slide and scanned with a compound microscope.

The concentration of eggs per $\mathrm{g}$ (epg) was estimated by dividing the number of eggs counted by the mass sampled under the coverslip. Assuming uniform distribution of both spores of Lycopodium and parasite eggs, the mass sampled under the coverslip was estimated by multiplying the number of spores of Lycopodium by the total weight of fecal sample used. The product was divided by the total number of Lycopodium spores (calculated by multiplying number of tablets used by the average number of spores).

Samples studied in the laboratories of paleoparasitology at Mar del Plata and FIOCRUZ were homogenized and allowed to spontaneously sediment (Lutz, 1919). Ten slides of each sample were prepared by mixing

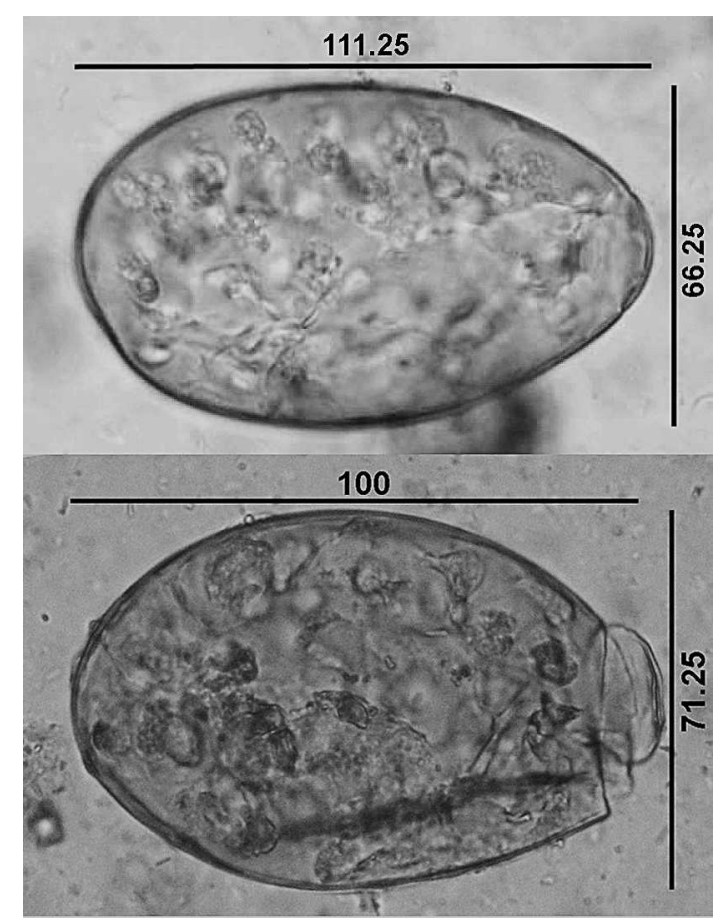

Figure 1. Echinostoma sp. eggs found in the coprolites. The measurements are in $\mu \mathrm{m}$. The opercular poles are oriented to the right. These eggs are especially well preserved and illustrate the size variation evident in the specimens.

a drop (approximately $0.5 \mathrm{ml}$ ) collected from the bottom with a drop of glycerin. The slides prepared were scanned with a compound microscope. Eggs detected were measured and identified using specialized literature (Yamaguti, 1975; Lamothe-Argumedo and García-Prieto, 1988; Anderson, 2000; Ash and Orihel, 2007).

\section{RESULTS}

From the 36 coprolites examined, 2 showed signs of diarrhea (coprolites 6 and 30), as indicated by a lamellar structure that resulted from the desiccation of watery stools. Five more displayed a flattened shape resulting from the desiccation of loose stools (coprolites 9, 12, 22, 26, 31).

The taxa found included digenetic trematodes and cestodes. Digenean eggs consistent in size and form with Echinostoma sp. were found (Fig. 1). Tapeworms were represented by Dipylidium caninum and a hymenolepidid species. The identification of $D$. caninum was based on the morphology of eggs found in packets. Only the embryophores were preserved from the hymenolepidid eggs, so diagnosis was possible only to Hymenolepididae. Digenean eggs were determined to be an unidentified species of the Echinostoma, based on the presence of an operculum and a thickening of the eggshell in the opposite pole to the operculum. We compared the archaeological eggs with eggs of Paragonimus and Fasciola species, but we eliminated the former taxon because the eggs we found lack the diagnostic operculum characteristic of species in this genus. Fasciola was also ruled out because of the larger size of eggs in fasciolid species. Therefore, we consider Echinostoma to be the best differential diagnosis.

The nematodes Ancylostoma duodenale (Dubini, 1843), Enterobius vermicularis (Linnaeus, 1758), and Trichuris trichiura (Linnaeus, 1771) were identified based on morphology and, in the case of $T$. trichiura, on the egg dimensions (Table I). 
TABLE I. Total number of eggs found in coprolites collected from Cueva de los Muertos Chiquitos, Mexico.

\begin{tabular}{|c|c|c|c|c|c|c|c|c|c|c|c|c|c|c|c|c|c|c|c|}
\hline Provenance & B3 & B3 & B3 & B3 & $\mathrm{C} 2$ & $\mathrm{C} 1$ & D2 & B4 & B4 & B4 & B4 & B4 & B4 & B4 & A2 & B3 & B4 & B4 & D2 \\
\hline \multicolumn{20}{|l|}{ Digenea } \\
\hline Echinostoma sp. & & $12^{*}$ & $1^{*}$ & & & & & & & & & & & & & & $5^{*}, 167 \dagger$ & & \\
\hline \multicolumn{20}{|l|}{ Cestoda } \\
\hline caninum & & & & & & $10^{*}$ & & & & & & & & $9 \dagger$ & & & & & \\
\hline \multicolumn{20}{|l|}{ Nematoda } \\
\hline $\begin{array}{l}\text { E. vermicularis } \\
\text { Ancylostoma }\end{array}$ & $1^{*}$ & $3 *, 3 \dagger$ & $2^{*}$ & & $3 \dagger$ & $3 *$ & $1^{*}$ & & $3^{*}$ & $4^{*}$ & $5 \dagger$ & $11 \dagger$ & $2 \dagger$ & & $4^{*}, 1 \dagger$ & $2^{*}, 7 \uparrow$ & $1^{*}$ & $1^{*}$ & $1^{*}, 2 \dagger$ \\
\hline duodenale & $5^{*}$ & & & & & & & & & & & & & & & & $25^{*}, 51 \dagger$ & $1^{*}$ & \\
\hline
\end{tabular}

* Infection detected by means of the spontaneous sedimentation technique.

$\uparrow$ Infection detected by means of the flotation technique.

The use of the flotation technique in Sheather's solution resulted in the detection of 10 positive coprolites. In these coprolites, 5 species of helminths were found (Table I). Eight of the coprolites $(22 \%)$ were positive for the pinworm E. vermicularis. One coprolite was positive for Echinostoma sp., D. caninum, A. duodenale, and T. trichiura (Table II).

The sedimentation technique revealed 14 positive coprolites and a total of 6 species of helminths (Table I). Individual eggs identified as human pinworm, E. vermicularis, were found in 12 coprolites (33\%). Echinostoma sp. and A. duodenale were found in 3 coprolites $(8 \%)$. One coprolite was positive for the hymenolepidid, D. caninum, and for T. trichiura.

The combined results of both techniques show that 19 coprolites were positive for 1 , or more, of 6 helminth species. Enterobius vermicularis showed the highest prevalence, occurring in $16(44 \%)$ of the samples. Echinostoma sp. and A. duodenale were found in 3 coprolites ( $8 \%$ ). The hymenolepidid, D. caninum, and T. trichiura were found in 2 coprolites each (6\%) (Table II).

The concentration of eggs per infected individual (in epg) was estimated as 2,702 $\pm 1,038$ epg for hookworms, 1,127 epg for whipworms, and 8,848 epg for Echinostoma sp. Pinworms were detected in 8 fecal pellets and the concentration ranged from 158 to 2,254 epg, with an average of $823 \pm 868 \mathrm{epg}$.

\section{DISCUSSION}

There are differences in results with variation in methods. For recovery and subsequent identification of helminth ova, the technique of spontaneous sedimentation appeared to be more sensitive, as it allowed the detection of 1 more species of parasite (Hymenolepidae) and 5 more infected individuals (Table II). This is consistent with early assessment of methods (Reinhard et al., 1988). The simplicity of the technique of spontaneous sedimentation may have allowed a greater number of eggs present in the sample to concentrate toward the bottom of the test tube. This, in addition to the greater number of slides prepared per sample, may have increased the chances of detecting eggs, even if the egg output was low. The flotation technique may result in false negatives if the mass of sediment to be re-suspended exceeds a critical mass that may dilute the Sheather's solution. False negatives may also result from the re-suspension of a small mass of sediment. The latter could be the case for coprolites 1, 2, 3, 5, 8, 11, and 12 (Table II), which were fiber rich. The presence of undigested mass in the coprolite reduces the proportional volume of digested contents and parasite ova.

Only 5 positive specimens were detected by both techniques (coprolites 2, 25, 27, 29, and 34; Table II) and resulted in the detection of the same species of parasite. The exception was coprolite 2, in which eggs of Echinostoma sp. were detected by means of the sedimentation technique. The method of flotation failed to detect parasites in 9 coprolites that were found to be positive by sedimentation (Table II). The latter method failed to detect eggs in 5 coprolites found infected by the former (Table II). Based on these observations, we recommend employing at least 2 different methods in subsequent studies.

The prevalence of parasites in coprolites from Cueva de los Muertos Chiquitos exceeds any published record from sites of the Greater Southwest in the United States (Reinhard et al., 1988; Reinhard, 1990, 1992) or from any site in the Americas in general (Gonçalves et al., 2003). The assemblage of parasites includes 6 species, 3 of which have a monoxenous and 3 a heteroxenous life cycle (Lamothe-Argumedo and García-Prieto, 1988; Anderson, 2000). The species showing direct patterns of transmission include A. duodenale, E. vermicularis, and $T$. trichiura. The rest of the species require at least 1 intermediate host to complete their life cycles. The assemblage of parasites suggest that the people from Cueva de los Muertos Chiquitos were exposed to a wide array of infections caused by parasites specific to humans and a set of zoonotic species. Inferences from the list may indicate that parasites could have been acquired via the ingestion of eggs, ingestion of food items carrying infective stages, and direct penetration.

Among the set of heteroxenous parasites detected in the present samples, all taxa may be associated with rodents and dogs, with humans serving occasionally as definitive hosts (LamotheArgumedo and García-Prieto, 1988). In archaeological sites, the 
TABLE II. Prevalence of parasite remains of 36 individual coprolites associated with a population of the Loma San Gabriel Culture, located in Cueva de los Muertos Chiquitos, El Zape, Mexico. Average measurements of the ova are presented in $\mu \mathrm{m}$. An estimation of the total prevalence, as well as the comparative results of both spontaneous sedimentation and flotation technique, is included.

\begin{tabular}{|c|c|c|c|c|}
\hline \multicolumn{5}{|l|}{ Digenea } \\
\hline Echinostoma sp. & $108 \times 66$ & $3 \%$ & $8 \%$ & $8 \%$ \\
\hline \multicolumn{5}{|l|}{ Cestoidea } \\
\hline $\begin{array}{l}\text { Hymenolepididae } \\
\text { Dipylidium sp. }\end{array}$ & $\begin{array}{l}22 \times 25 \\
23 \times 18\end{array}$ & - & $\begin{array}{l}3 \% \\
3 \%\end{array}$ & $\begin{array}{l}3 \% \\
6 \%\end{array}$ \\
\hline
\end{tabular}

presence of parasites of rodents in human feces has been associated with the practice of storing agricultural goods in granaries (Reinhard, 1987; Reinhard et al., 2007; Reinhard and Bryant, 2008). Grain containers attract arthropods and granivorous rodents that may feed on the grains and the fauna associated with them. Coleopterans and rodents serve as intermediate and definitive hosts for certain species of hymenolepidid tapeworms (Gardner, 1985; Gardner and Schmidt, 1988) although 1 species of hymenolepidid, Hymenolepis nana, also has an alternate, direct life cycle. Uncertainty for the taxonomic identity of the hymenolepidid eggs prevents us from determining a pattern of transmission that may be compared against the agricultural practices of the people of Loma San Gabriel (Kelley, 1956, 1971; Brooks et al., 1962; Foster, 1985). Dipylidium caninum use fleas as intermediate hosts. It is most commonly a parasite of dogs, but humans can be infected by eating fleas or lice. The presence of Echinostoma sp. may be a result of the hunting habits of the people who inhabited this cave. Echinostoma spp. include several generalist species that may occur in birds and mammals. Among them, Echinostoma revolutum (Froelich, 1802) is a species that is found in cricetine rodents, carnivores, and birds (Yamaguti, 1975) and infects people in Mexico (Lamothe-Argumedo and GarcíaPrieto, 1988). The infection is acquired by eating snails or frogs containing the metacercaria of this trematode (Yamaguti, 1975). The pathology resulting from the infection of these 3 species would depend on the number of worms occurring in the patient. Typically, they may include diarrhea, abdominal pain, and headaches (Lamothe-Argumedo and García-Prieto, 1988), although heavy infections may cause anemia and other complications.

Secondary contamination of the samples by rodents defecating on the coprolites can be ruled out because the sealing of the original midden prevented rodents from gaining access to the burials, evidenced by the fact that the burial food offerings remained intact until their excavation (Brooks et al., 1962; Brooks and Brooks, 1978, 1980).

The 3 nematode species infect their host via direct transmission. Among them, both the pinworm and whipworm are transmitted orally, and the hookworm is generally transmitted via direct penetration of the skin (Miller, 1979).

Until the present, Ancestral Puebloans have had the highest documented archaeological prevalence of pinworm (Hugot et al., 1999). The high prevalence of pinworms (44\%) in the coprolites examined exceeds the prevalence of this parasite in localities of the
Greater Southwest. In populations of the Colorado Plateau, prevalence for this nematode ranged from 11 to $29 \%$ (Reinhard, 1988). Hugot et al. (1999) found the highest prevalence of prehistoric pinworm in walled structures built in caves. They make a case that eggs become airborne in such environments and result in infection through the inhalation of eggs and egg-contamination of food and water. The high prevalence of pinworm at the Cueva de los Muertos Chiquitos is consistent with this finding.

Because of the characteristics of their life cycle (Anderson, 2000), eggs of pinworms are usually found in the perianal folds of people and are seldom found in feces. This characteristic has served as the foundation to infer that a prevalence of 5\% may indicate the presence of this nematode in almost all the individuals of a population (Fry, 1977). Clearly, the people who lived at Cueva de los Muertos Chiquitos had a serious problem with pinworm infection. Heavy infections with pinworms may cause hyperemia in the blood vessels of the serosa surrounding the appendix, yet they do not induce a severe inflammatory response. The high prevalence of pinworms is consistent with the fact that people from Loma San Gabriel lived in crowded groups (Kelley, 1956, 1971; Foster, 1985, 1986), which can facilitate the transmission of the parasite.

Because of their direct pattern of transmission, both hookworm and whipworms are common parasites of people and occur in high prevalence worldwide (Brooker, 2010). Currently, both species are found in Mexico (Lamothe-Argumedo and García-Prieto, 1988) and their remains had been documented in archaeological sites of the Greater Southwest and other parts of the continent (Allison et al., 1974; Reinhard, 1987; Gonçalves et al., 2003). In the present study, both hookworm and whipworm occurred with a prevalence of $8 \%$ and $6 \%$, respectively. Although a precise estimation of the morbidity and mortality caused by these 2 parasitoses may not be possible, it has been estimated that severe trichuriasis affects $5 \%$ of infected children under the age of 15 , and anemia-inducing infections by hookworm may affect $6 \%$ of infected individuals (Brooker, 2010).

Several species of whipworms are known to infect humans including the specific T. trichiura and the zoonotic Trichuris suis (Schrank, 1788) (Lamothe-Argumedo and García-Prieto, 1988; Anderson, 2000). These whipworm species may have evolved parallel to the evolution of humans ( $T$. trichiura) and pigs $(T$. suis). The absence of pigs in the prehistoric New World indicates that $T$. trichiura infected people at Cueva de los Muertos Chiquitos. Severe trichuriasis affects children and may induce 
dysentery, anemia, and rectal prolapse (Brooker, 2010) even before the worm reaches sexual maturity, which happens between 2 and 3 mo post-infection (Anderson, 2000).

The pattern of transmission of hookworms includes the hatching of the larvae in the soil and an active migration of the infective stage from the moist soil through the skin into the lungs and then the small intestine, with a prepatent period of about 43 days (Miller, 1979; Anderson, 2000). Infections by hookworms in children are known to be lethal in post-infection periods as short as 30 days (Miller, 1971) and are known to induce high mortality in children 1 to $5 \mathrm{yr}$ of age in developing countries (Zimmerman, 1946; Bwimbo, 1970). We did not find any blood or a high concentration of watery mucus in the coprolites (Miller, 1971), which are indicators of acute infections. However, the concentration of 2,702 hookworm epg of feces found in 1 infected individual suggests that inhabitants of the cave would have been exposed to heavy infections. Heavy infections are known to cause severe pathology before worms reach sexual maturity (Miller, 1971, 1979). Mechanical damage of the lungs is caused when larvae transgress the pulmonary circulation to the alveoli, causing internal hemorrhaging, and induces death within 24-72 hr after experimental infection of puppies (Miller, 1971).

The presence of these parasites is an indicator of the poor sanitary conditions of the cave environs and the low hygiene levels of the cave inhabitants. The finding of hymenolepidid tapeworms, and $D$. caninum, suggests the presence of intermediate hosts in the settlements. The presence of whipworms and hookworms indicate defecation in, or in the vicinity of, the dwelling or work areas such as agricultural fields (Reinhard, 1992, 2008; Reinhard and Bryant, 2008; Walker et al., 2009). The latter observation could be associated with the high mortality observed in children $2 \mathrm{yr}$ or younger. The infections caused by parasites may cause a lethal effect on children as a result of the combination of malnutrition and the recurrent uptake of nutrients (especially vitamin B12) by the parasites. The combined results could become exacerbated during periods of drought and famine (Walker et al., 2009), which could have resulted in the high and traumatic mortality levels of the children buried in Cueva de los Muertos Chiquitos (Brooks and Brooks, 1978).

In the archaeological record, increased pinworm prevalence is associated with sedentary, crowded villages (Reinhard, 1987, 1992; Santoro et al., 2003). Reinhard (1992) defined a positive, and significant, correlation between pinworm prevalence in coprolites and cranial lesions from anemia in skeletal populations at the same sites. Recognizing the fact that pinworms do not cause serious pathology such as anemia, Reinhard (1992) made a case that pinworms are a good proxy gauge of pathogens associated with poor sanitation. These include water- and food-borne pathogens as well as air-borne pathogens. The sites with the highest prevalence of lesions attributable to anemia also had a diversity of parasites. Applying this model to Cueva de los Muertos Chiquitos, it is likely that anemia was also a problem faced by the Loma San Gabriel people.

Our results are the first reconstruction of the parasitoses hosted by the people of the Loma San Gabriel culture. With the available results, we have detected the presence of diseaseinducing species including hookworms, whipworms, and several cestodes. It is not possible at this point to find a correlation between the death of the children from Cueva de los Muertos Chiquitos and the parasites discovered. However, future integration of our data with skeletal pathology may reveal connections between parasitoses and morbidity-mortality at the site. At our study area, skeletal remains and coprolites were found in the same cultural association; therefore, the parasite data are directly applicable to a skeletal series. This is due to the fact that a midden (trash deposit) containing coprolites was also used as an area for burial of the dead (Brooks and Brooks, 1978). The Cueva de los Muertos Chiquitos analysis suggests that some parasite species entered into the southwestern United States from people in Mesoamerica. Hookworm became established among agricultural peoples in the Colorado Plateau after 900-yr-ago. The finding of hookworm in Durango, Mexico, $500 \mathrm{yr}$ earlier indicates that hookworm was well established in Mesoamerica at an earlier time. Araújo et al. (2008) presented the value of using parasites as markers or probes for ancient human migrations. The transfer of hookworm from Mesoamerica to the Southwestern United States indicates that interaction between prehistoric peoples in these areas occurred. Importantly, prehistoric hookworms in the southwest were found at sites within the sphere of influence of the Ancestral Pueblo culture of Chaco Canyon. The archaeology of Chaco Canyon is replete with Mesoamerican cultural characteristics, ranging from pottery styles to trade goods such as cacao. Archaeologists have increasingly recognized Mesoamerican influences in Chaco Ancestral Puebloans (Lekson, 2009). The discovery of a hookworm connection between the Mesoamerica and the Ancestral Pueblo culture is the first pathogen indicator of Mesoamerican presence in the southwest.

\section{ACKNOWLEDGMENTS}

This research was made possible by a grant from the Programa de Professor Visitante Estrangeiro from the Coordenação de Aperfeiçoamento de Pessoal de Nível Superior, Brazil. Thanks also to the 2010 University of Nebraska-Lincoln (UNL) archaeoparasitology class participants who rechecked the samples processed at UNL, especially Kelsey Kumm, Nicole Searcey, and Terry Haverkost.

\section{LITERATURE CITED}

Allison, M. J., A. Pezzia, I. Hasegawa, and E. Gerszten. 1974. A case of hookworm infestation in a pre-Columbian American. American Journal of Physical Anthropology 41: 103-106.

Anderson, R. C. 2000. Nematode parasites of vertebrates. Their development and transmission, 2nd. CAB International, Farnham Royal, U.K., 650 p.

Araújo, A., And L. F. Ferreira. 2000. Paleoparasitology and the antiquity of human host-parasite relationships. Memórias do Instituto Oswaldo Cruz 95: 89-93.

, A. M. Jansen, F. Bouchet, K. Reinhard, and L. F. Ferreira. 2003. Parasitism, the diversity of life, and paleoparasitology. Memórias do Instituto Oswaldo Cruz 98: 5-11.

- , K. Reinhard, L. F. Ferreira, and S. Gardner. 2008. Parasites as probes for prehistoric migrations? Trends in Parasitology 24: 112 115.

Ash, L. R., And T. C. Orinel. 2007. Ash and Orihel's Atlas of human parasitology. 5th American Society for Clinical Pathology Press, Chicago, Illinois, 540 p.

Bouchet, F., N. Guidon, K. Dittmar, S. Harter, L. F. Ferreira, S. M Chaves, K. Reinhard, and A. Araúso. 2003. Parasite remains in archaeological sites. Memórias do Instituto Oswaldo Cruz 98: 47-52.

Brooker, S. 2010. Estimating the global distribution and disease burden of intestinal nematode infections: Adding up the numbers-A review. International Journal for Parasitology 40: 1137-1144.

Brooks, R. H., L. Kaplan, H. C. Cutler, and T. W. Whitaker. 1962. Plant material from a cave on the Rio Zape, Durango, Mexico. American Antiquity 27: 356-369. 
Brooks, S. T., AND R. H. Brooks. 1978. Paleoepidemiology as a possible interpretation of multiple child burials near Zape Chico, Durango, Mexico. In Across the Chichimec sea: Papers in honor of J. Charles Kelley; J. C. Kelley, C. L. Riley, and B. C. Hedrick (eds.). Southern Illinois University Press, Carbondale, Illinois, p. 96-101.

, AND - 1980. Cranial deformation: Possible evidence of Pochteca trading movements. Transactions of the Illinois State Academy of Sciences 72: 1-12.

Bryant, V. M. 1974. The E. O. Callen collection. American Antiquity 39: 497-498.

1975. The Callen coprolitic reference collection. Economic Botany 29: $236-237$.

Bwimbo, N. O. 1970. Common causes of death in children at Mulago Hospital, Kampala, Uganda. Clinical Pediatrics 9: 691-694.

Callen, E. O. 1965. Food habits of some pre-Columbian Mexican Indians. Economic Botany 19: 335-343.

. 1967. Analysis of Tehuacán coprolites. In The prehistory of the Tehuacán valley. Vol. I. Environment and subsistence, D. S. Byers (ed.). University of Texas Press, Austin, Texas, p. 261-289.

—, AND T. W. M. CAmeron. 1960. A prehistoric diet revealed in coprolites. The New Scientist 8: $35-40$.

Costa, M. A., C. Matheson, L. Iachetta, A. Llagostera, and O. Appenzeller. 2009. Ancient leishmaniasis in a highland desert of northern Chile. PLoS ONE 4: e6983.

Ferreira, L. F., A. AraúJo, AND U. Confalonieri. 1979. Subsídios para a paleoparasitologia do Brasil I-Parasitos encontrados em coprólitos no município de Unaí, Minas Gerais. Campinas, São Paulo, Brazil, 56 p.

, C. Britto, A. Cardoso, O. Fernandes, K. Reinhard, and A. Araúuo. 2000. Paleoparasitology of Chagas' disease revealed by infected tissues of Chilean mummies. Acta Tropica 75: 79-84.

Foster, M. S. 1985. The Loma San Gabriel occupation of Zacatecas and Durango, México. In Archaeology of west and northwest Mesoamérica, M. S. Foster and P. C. Weigand (eds.). Westview Press, Boulder, Colorado, p. 327-352.

- 1986. The Weicker site: A Loma San Gabriel hamlet in Durango, Mexico. Journal of Field Archaeology 13: 7-19.

FrY, G. F. 1977. Analysis of prehistoric coprolites from Utah. University of Utah Anthropological Papers 97. University of Utah Press, Salt Lake City, Utah, 62 p.

GARDNER, S. L. 1985. Helminth parasites of Thomomys bulbivorus (Richardson) (Rodentia: Geomyidae), with the description of a new species of Hymenolepis (Cestoda). Canadian Journal of Zoology 63: 1463-1469.

- AND D. W. Duszynski. 1990. Polymorphism of eimeriian oocysts can be a problem in naturally infected hosts: An example from subterranean rodents in Bolivia. Journal of Parasitology 76: 805-811. , AND G. D. Schmidt. 1988. Cestodes of the genus Hymenolepis Weinland, 1858 sensu stricto from pocket gophers Geomys and Thomomys spp. (Rodentia: Geomyidae) in Colorado and Oregon, with a discriminant analysis of four species of Hymenolepis. Canadian Journal of Zoology 66: 896-903.

Gonçalves, M. L. C., A. Araújo, and L. F. Ferreira. 2003. Human intestinal parasites in the past: New findings and a review. Memórias do Instituto Oswaldo Cruz 98: 103-118.

Guhl, F., C. Jaramillo, R. Yockteng, G. A. Vallejo, and F. C. Arroyo. 1997. Trypanosoma cruzi DNA in human mummies. Lancet 349: 1370.

Hugot, J. P., K. J. Reinhard, S. L. Gardner, and S. Morand. 1999. Human enterobiasis in evolution: Origin, specificity and transmission. Parasite 6: 201-208.

Kelley, J. C. 1956. Settlement patterns in North-Central México. In Prehistoric settlement patterns in the New World, G. R. Willey (ed.). Viking Fund Publications in Anthropology, New York, New York, p. 128-139.

. 1971. Archaeology of the northern frontier. Zacatecas and Durango. In Archaeology of Mesoamérica, Part Two. Handbook of Middle American Indians, Vol. 11, G. F. Ekhoin and Ignacio Bernal (eds.). University of Texas Press, Austin, Texas, p. 768-804.

Lamothe-Argumedo, R., and L. García-Prieto. 1988. Helmintiasis del hombre en México. Tratamiento y profilaxis, 1 st. AGT, Mexico City, D.F., 139 p.

Lekson, S. H. 2009. A history of the ancient Southwest. School for Advanced Research Press Press, Santa Fe, New Mexico, 452 p.
Lutz, A. 1919. Schistosoma mansoni e a schistosomatose segundo observações feitas no Brasil. Memórias do Instituto Oswaldo Cruz 1: 121-155.

McNeISH, R. S. 1967. An interdisciplinary approach to an archaeological problem. In The prehistory of the Tehuacán Valley. Vol. I. Environment and subsistence, D.S. Byers (ed.). University of Texas Press, Austin, Texas, p. 290-309.

Miller, T. A. 1971. Vaccination against the canine hookworm diseases. Advances in Parasitology 9: 153-183.

. 1979. Hookworm infection in man. Advances in Parasitology 17: 315-384.

Pizzi, T., And H. Schenone. 1954. Hallazgo de huevos de Trichuris trichiura en contenido intestinal de un cuerpo arqueológico incaico. Boletín Chileno de Parasitología 9: 73-75.

Pritchard, M. H., And G. O. W. Kruse. 1982. The collection and preservation of animal parasites. University of Nebraska Press, Lincoln, Nebraska, $141 \mathrm{p}$.

ReInHARD, K. 1987. Cultural ecology of parasitism on the Colorado Plateau as evidenced by coprology. American Journal of Physical Anthropology 77: 355-366.

. 1990. Archaeoparasitology in North America. American Journal of Physical Anthropology 82: 145-163.

1992. Parasitology as an interpretive tool in archaeology. American Antiquity 57: 231-245.

. 2008. Parasite pathoecology of Chacoan Great Houses: The healthiest and wormiest Ancestral Puebloans. In Chaco's northern prodigies; Salmon, Aztec, and the ascendancy of the Middle San Juan region after AD 1100, P. F. Reed (ed.). University of Utah Press, Salt Lake City, Utah, p. 86-95.

, J. R. Ambler, and C. R. Szuter. 2007. Hunter-gatherer use of small animal food resources: Coprolite evidence. International Journal of Osteoarchaeology 17: 416-428.

$\longrightarrow$, AND V. M. BRYANT. 1992. Coprolite analysis: A biological perspective on archaeology. In Advances in archaeological method and theory, M. B. Schiffer (ed.). University of Arizona Press, Tucson, Arizona, p. 245-288.

— AND . 2008. Pathoecology and the future of coprolite studies. In Reanalysis and reinterpretation in southwestern bioarchaeology, A. W. M. Stodder (ed.). Arizona State University Press, Tempe, Arizona, p. 199-216.

- U. Confalonieri, L. F. Ferreira, B. Herrmann, and A. G. ArAúso. 1988. Recovery of parasite remains from coprolites and latrines: Aspects of paleoparasitological technique. Homo 37: 217-239.

Samuels, R. 1965. Parasitological study of long dried fecal samples. American Antiquity 31: 175-179.

Santoro, C., S. D. Vinton, And K. Reinhard. 2003. Inca expansion and parasitism in the Lluta Valley: Preliminary data. Memorias do Instituto do Oswaldo Cruz 98: 161-163.

Sianto, L., K. J. Reinhard, M. Chame, S. Chaves, S. Mendonca, M. L. C. Goncalves, A. Fernandes, L. F. Ferreira, and A. Araújo. 2005. The finding of Echinostoma (Trematoda: Digenea) and hookworm eggs in coprolites collected from a Brazilian mummified body dated 600-1,200 years before present. Journal of Parasitology 91: 972-975.

SzIDAT, L. 1944. Über die Erhaltungsfähigkeit von Helmintheneiern in Vor-und Frühgeschichtlichen Moorleichen. Zeitschrift für Parasitenkunde 13: 265-274.

TAYLOR, E. L. 1955. Parasitic helminths in mediaeval remains. Veterinary Record 67: 216-218.

Tito, R. Y., S. Macmil, G. Wiley, F. Najar, L. Cleeland, C. Qu, P. Wang, F. Romagne, S. Leonard, A. J. Ruiz et al. 2008. Phylotyping and functional analysis of two ancient human microbiomes. PLoS ONE 3: e3703.

Walker, P. L., R. R. Bathurst, R. Richman, T. Gjerdrum, and V. A. Andrushro. 2009. The causes of porotic hyperostosis and cribra orbitalia: A reappraisal of the iron-deficiency-anemia hypothesis. American Journal of Physical Anthropology 139: 109-125.

Warnock, P., AND K. J. ReInhard. 1992. Methods of extracting pollen and parasite eggs from latrine soils. Journal Archaeological Science 19: 261-264.

Yamaguti, S. 1975. A synoptical review of life histories of digenetic trematodes of vertebrates: With special reference to the morphology of their larval forms. Ministry of Education, Kyoto, Japan, 590 p.

Zimmerman, R. M. 1946. Fatal hookworm disease in infancy and childhood on Guam. American Journal of Pathology 22: 1081-1100. 